\title{
Plant Cuttings
}

Annals of Botany 121: iv-vii, 2018

\section{News in Botany: Nigel Chaffey presents a round-up of plant-based items from the world's media}

\section{Mammoth news: Bees help plants}

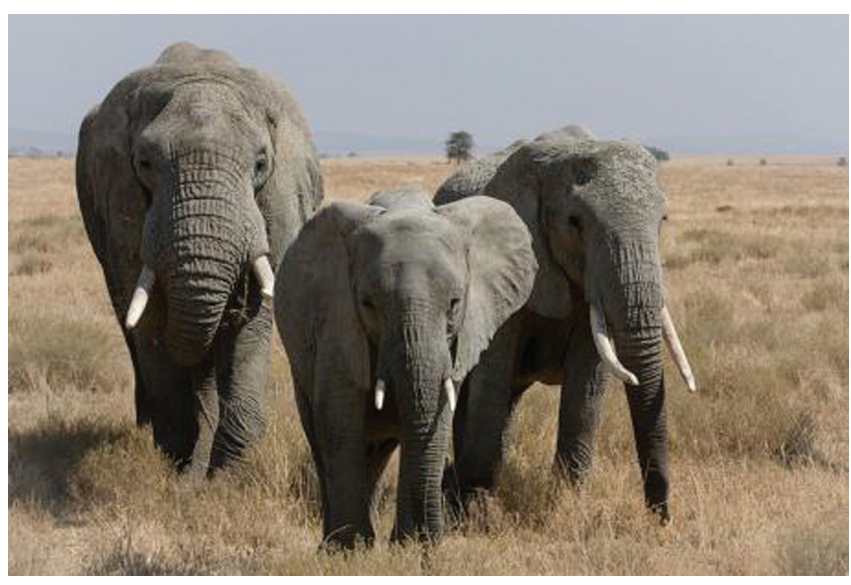

What! That's news?? Surely everybody knows that many plants are pollinated by bees ${ }^{[1,2]}$ ? Hopefully, yes, but this item is not about that well-known plant-insect association. OK, but does it feature mammoths ${ }^{[3]}$ ? No, but it does have an elephantine ${ }^{[4]}$ dimension. Having laboured long and hard to plant and grow crops - to feed the family, and maybe have some surplus to sell to, or trade with, others - the last thing you need is for those plants to be trampled by ... elephants. Yet, that is a major concern in parts of Africa (where the African elephant ${ }^{[5,6]}$ is an ever-present 'threat' to other life forms $\left.{ }^{[7,8]}\right)$. A biocontrol ${ }^{[9]}$ method to ward off the elephants that's having success in southern Africa is the humble bee. Despite its apparent toughness and thickness, the elephant's skin is rather sensitive to bee stings ${ }^{[10]}$, and there is the real danger that a bee sting within the trunk could potentially lead to suffocation. So, elephants not only avoid bees (sensible animals that they are), but also the places where the bees buzz. Can this behaviour be exploited as a crop-damage-mitigation approach? Yes. Experiments testing effectiveness of bees versus wire netting to deter elephant damage to marula trees (Sclerocarya birrea ${ }^{[1,12,13]}$ in an area near the Kruger National Park ${ }^{[14]}$ in South Africa concluded that the honeybee approach was a qualified success*[15]. Which is arguably a triple bonus; if bees' nests are located close to crops, elephants are kept away from them, there is the potential for a honey ${ }^{[16,17]}$ harvest for the farmer and his family (which might also be sold...), and pollination of those crops that the bees visit when they're not engaged in pachyderm ${ }^{[18]}$-bothering duties**. A sort of 'wing'win $^{[19]}$ situation: Thank you, bees!

*Some of you may be thinking: Rather than use bees - which could sting humans - why not use mice, given that mice are creatures which elephants are, anecdotally, afraid of ${ }^{[25,26]}$ ? Well, whilst mice might get rid of the elephants, they are primarily herbivores ${ }^{[27,28]}$, and therefore would be likely to feast on the crops. Thereby replacing one pesky mammal with another... At least the bees only take a bit of pollen - and do something useful with it! Although it is argued that honeybees aren't necessarily the right sort of bees to be encouraging ${ }^{[29]}$ for a more environmentally-considerate strategy...
**AND, keeping these African honeybees (Apis mellifera ssp. scutellata $^{[30,31]}$ ) in Africa on elephant patrol will also reduce the chances of them getting out of Africa and inter-breeding with other bee species and 'Africanising' them into aggressive aerial attackers of humans ${ }^{[32,33]}$.

[Ed. - Encouragingly, this honeybee approach also seems to work against Indian elephants ${ }^{[20,21]}-$ in Thailand ${ }^{[22]}$ at least ${ }^{[23]}$. For those who appreciate a reminder of the differences between African and Indian elephants, a handy guide can be found at ${ }^{[24]}$.]

Image from: Wikimedia Commons

\section{References}

[1] Tom Breeze et al., Agriculture, Ecosystems and Environment 142: 137-143, 2011; doi:10.1016/j.agee.2011.03.020

[2] http://beefarmers.co.uk/pollination/

[3] http://www.bbc.co.uk/nature/life/Mammoth

[4] http://www.dictionary.com/browse/mammoth

[5] https://www.worldwildlife.org/species/african-elephant

[6] http://www.iucnredlist.org/details/12392/0

[7] ht tps://www.mnn.com/earth-matters/animals/ photos/15-cute-animals-that-could-kill-you/elephant

[8] http://dangerous-animals-pets.blogspot.co.uk/p/dangerous-elephants.html

[9] https://www.cabi.org/projects/controlling-invasive-species/ biocontrol/

[10] https://phys.org/news/2017-12-south-africa-bees-elephants-trampling.html?utm_source=nwletter\&utm_medium=email\&utm campaign=daily-nwletter

[11] http://pza.sanbi.org/sclerocarya-birrea

[12] http://powo.science.kew.org/taxon/urn:1sid:ipni. org:names:71162-1

[13] http://africafreak.com/the-marula-fruit-african-booze-for-wildanimals-or-total-myth/

[14] http://www.krugerpark.co.za/

[15] Robin Cook et al. (Biological Conservation 217: 329-336, 2017; https://doi.org/10.1016/j.biocon.2017.11.024

[16] https://www.livescience.com/37611-what-is-honey-honeybees. html

[17] https://www.vegansociety.com/go-vegan/why-honey-not-vegan

[18] http://www.dictionary.com/browse/pachyderm

[19] https://dictionary.cambridge.org/dictionary/english/win-win

[20] https://a-z-animals.com/animals/indian-elephant/

[21] http://www.iucnredlist.org/details/7140/0

[22] https://www.lonelyplanet.com/thailand

[23] https://phys.org/news/2016-08-thai-farmers-bee-elephants.html

[24] http://www.majordifferences.com/2018/01/10-differencesbetween-african-elephant-and-indian-elephant-vs-african-elephant-vs-asian-elephant.html\#.WlNhLHnLgdU]

[25] https://www.livescience.com/33261-elephants-afraid-of-mice-. html

[26] http://www.discovery.com/tv-shows/mythbusters/ mythbusters-database/elephants-afraid-mice/

[27] https://www.livescience.com/28028-mice.html

[28] https://animalcorner.co.uk/animals/mice/

[29] https://www.npr.org/sections/thesalt/2018/01/27/581007165/ honeybees-help-farmers-but-they-dont-help-the-environment 
[30] http://www.atlashymenoptera.net/page.asp?id=238

[31] http://www.eol.org/data_objects/32174153

[32] https://www.si.edu/spotlight/buginfo/killbee

[33] http://entnemdept.ufl.edu/creatures/misc/bees/ahb.htm

\section{Introducing The Global Flora}

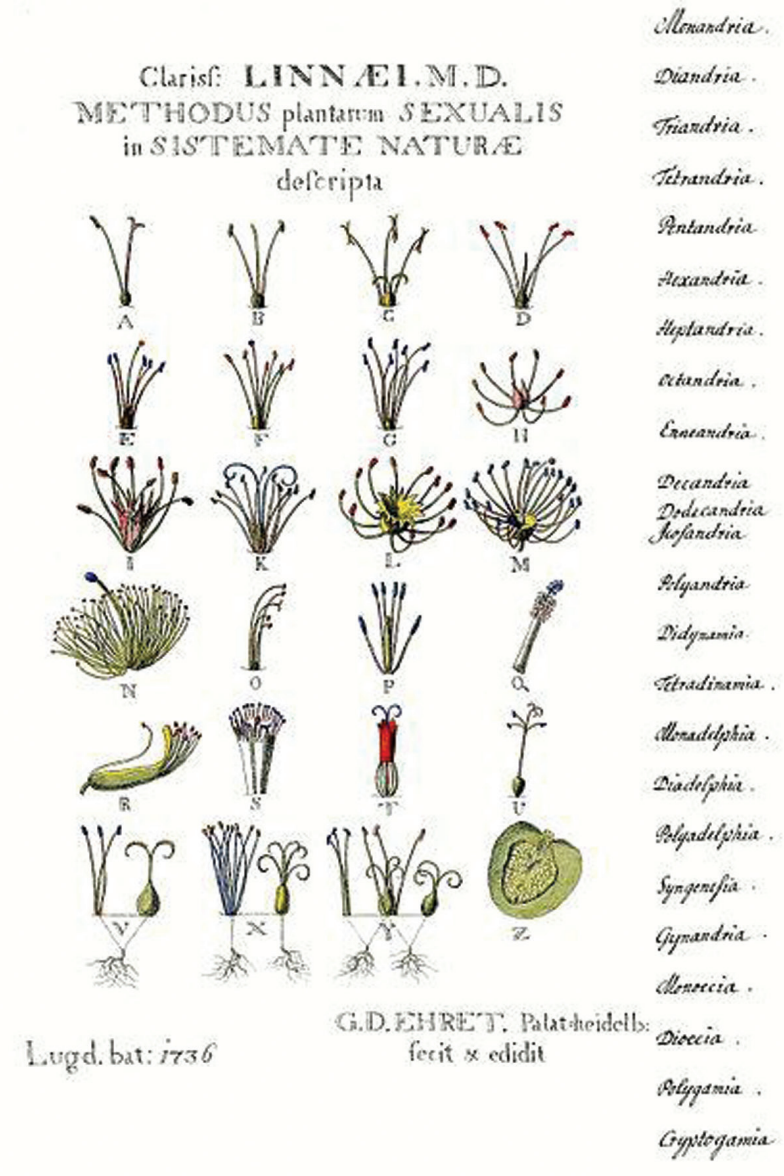

At Cuttings HQ we love a new botany journal - even if it's technically described as a serial. So, we were really pleased to find out about The Global Flora ${ }^{[1]}$; the first issue was launched in January 2018. Published by Plant Gateway $\operatorname{Ltd}^{[2]}$, this new publishing initiative is intended as a 'practical flora to vascular plant species of the world'. Now what could be more botanical than that? [Ed. - one that deals with all phyla of the Plant Kingdom $^{[3,4]}$, i.e. including the non-vascular ${ }^{[5]} \operatorname{mosses}^{[6,7]}$, liverworts $^{[7,8]}$, and hornworts ${ }^{[9,10]} \ldots$ ?] Agreed, but we are where we are, so let's focus on what we have rather than what we don't - currently! - have. According to Chief-Editors James Byng and Maarten Christenhusz, the intention of The Global Flora is 'to provide accepted species level classifications for all vascular plant families [i.e. those within the fern ${ }^{[1]}$ and fern-allies $^{[12,13]}$, gymnosperm ${ }^{[14,15]}$, and angiosperm ${ }^{[16,17]}$ plant groups] based on available or generated molecular data and re-examining the literature and herbarium specimens in major herbaria*'. The goal therefore is 'to provide a current, balanced and practical taxonomy reflecting evolutionary relationships'. The Global Flora will be published frequently and at regular intervals. It will be amply illustrated and should appeal to many different users [e.g. ecologists, conservationists, gardeners and other plant enthusiasts in the applied sciences, i.e. not just the rather restricted audience of practising taxonomists]. True to its word, its first article - 'The phylogeny of angiosperms poster' by James Byng et al. ${ }^{[18]}$ is a full-colour visual overview of the relationships of all angiosperm families currently recognised by APG IV (Angiosperm Phylogeny Group ${ }^{[19 ; 20]}$ ). It features stunning colour images of flowers of 269 families in-text, and is accompanied by a magnificent, free to download ${ }^{[21]}$, A0 size [a wall-plastering $841 \times 1189 \mathrm{~mm} ; 33.1 \times 46.8$ inches], poster of the paper's phylogenetic relationships in one view, along with those amazing full-colour flower images. That graphic is a truly amazing visual experience**. Such a pity that it is likely to be out-of-date in the (very) near future as the evolutionary relationships continue to be assessed and re-evaluated, and changed. Still, it records our current understanding of something that continues to evolve as our understanding and techniques of phylogenetic analysis improve, and is therefore a valid historic document. However, and arguably even more gratifying, is the stated commitment that The Global Flora will share royalties - presumably from subscriptions to the journal - with authors, and compensate reviewers and editors for their respective duties. The journal views this as important to maintain momentum for future studies to be undertaken, 'because relatively few institutions provide time and funds for researchers to do this time-consuming, yet crucially important work'. And an 'unspoken consensus of many taxonomists is that the historical lack of remuneration for this type of research is a primary reason that taxonomy does not progress more rapidly' $* * *$. Where royalties are unable to be transferred, the sums will contribute to a Global Flora Small Grants Fund that will be used to allow future contributors to undertake herbarium visits and to generate data for future analysis and publication in The Global Flora. Both an outlet - and an incentive - for traditional Botany: What's not to like?

*Although it's not stated in that editorial what the definition of 'major' is, for those interested in lists of things, the latest census of the world's herbaria ${ }^{[22]}$ - as at $1^{\text {st }}$ December, 2017 - published by Index Herbariorum ${ }^{[23 ; 24]}$ states that there are 3001 active herbaria in 176 countries of the world, containing $387,007,790$ specimens. That number may well need revising upwards if all the world's private herbaria are accounted for; the importance of these often unappreciated resources and repositories is reviewed by Francesco Roma-Marzio et al. ${ }^{[25]}$.

** Intriguingly, a non-illustrated version of a poster on angiosperm phylogeny ${ }^{[26]}$ by Theodor Cole et al. is available at ${ }^{[27]}$.

***For an insight into local concerns, but which likely mirror those more globally, over taxonomic work generally, look at the Australian Government's report entitled 'State of the science of taxonomy in Australia: results of the 2016 Survey of Taxonomic Capacity' ${ }^{[28]}$, and 'case studies' in Peter Hannam's article in The Sydney Morning Herald ${ }^{[29]}$.

[Ed. - for those who now realise they have a yearning to know more about the value of herbarium collections, we recommend papers by Estevao Souza and Julie Hawkins ${ }^{[30]}$, J. Mason Heberling and Bonnie Isaac ${ }^{[31]}$, and Marcia Yerman (in The American Gardener November/December 2017 ${ }^{[32]}$ ). And, if you're still wondering what a herbarium is and does, a good introduction is provided by James Smith $^{[33]}$.]

Image from: Wikimedia Commons

\section{References}

[1] http://www.plantgateway.com/about-globalflora/

[2] http://www.plantgateway.com/

[3] https://byjus.com/biology/plant-kingdom-plantae/

[4] http://eol.org/pages/281/overview 
[5] http://projects.ncsu.edu/project/bio181de/Lab/plant_phylogeny/ non-vascular.html

[6] https://basicbiology.net/plants/non-vascular/mosses/

[7] http://www.biology4kids.com/files/plants_moss.html

[8] https://www.anbg.gov.au/bryophyte/what-is-liverwort.html

[9] http://www.ucmp.berkeley.edu/plants/anthocerotophyta.html

[10] http://lifeofplant.blogspot.co.uk/2011/03/hornworts.html

[11] https://www.britannica.com/plant/fern

[12] http://www.tulane.edu/ bfleury/diversity/labguide/mossfern.html

[13] https://www.cliffsnotes.com/study-guides/biology/plant-biology/ seedless-vascular-plants/the-ferns-and-their-allies

[14] https://www.diffen.com/difference/Angiosperms_vs_Gymnosperms

[15] http://www.conifers.org/zz/gymnosperms.php

[16] http://tolweb.org/Angiosperms

[17] h t t p s:// w w w . s c i e n cedirect.com/topics / agricultural-and-biological-sciences/angiosperm

[18] http://www.plantgateway.com/download/2127/

[19] https://www.kew.org/blogs/kew-science/apg-classification-consensus

[20] http://www.mobot.org/MOBOT/research/APweb/

[21] http://www.plantgateway.com/poster/

[22] http://sweetgum.nybg.org/science/docs/The_Worlds_ Herbaria_2017_5_Jan_2018.pdf

[23] http://sweetgum.nybg.org/science/ih/

[24] https://www.nybg.org/science-project/index-herbariorum-upgrade/

[25] Italian Botanist 3: 7-15, 2017; doi: 10.3897/italianbotanist.3.12097

[26] https://peerj.com/preprints/2320.pdf

[27] https://peerj.com/preprints/2320/

[28] http://www.environment.gov.au/system/files/resources/8a490d6de96b-46bb-9462-049a83290946/files/state-science-taxonomyaustralia-2016-v1.pdf

[29] http://www.smh.com.au/environment/animals/absurdly-smalltaxonomy-funds-shrivel-amid-rising-threats-and-discoveries20180124-h0nhzn.html

[30] Economic Botany 71: 1-12, 2017; https://doi.org/10.1007/ s12231-017-9367-1

[31] American Journal of Botany 104 (7): 963-965, 2017; doi: 10.3732/ ajb. 1700125

[32] https://www.nybg.org/content/uploads/2018/01/AmericanGardener_Herbarium_NovDec-2017.pdf

[33] http://digitalcommons.humboldt.edu/botany_jps/36

\section{Gardens, truly the best medicine!}

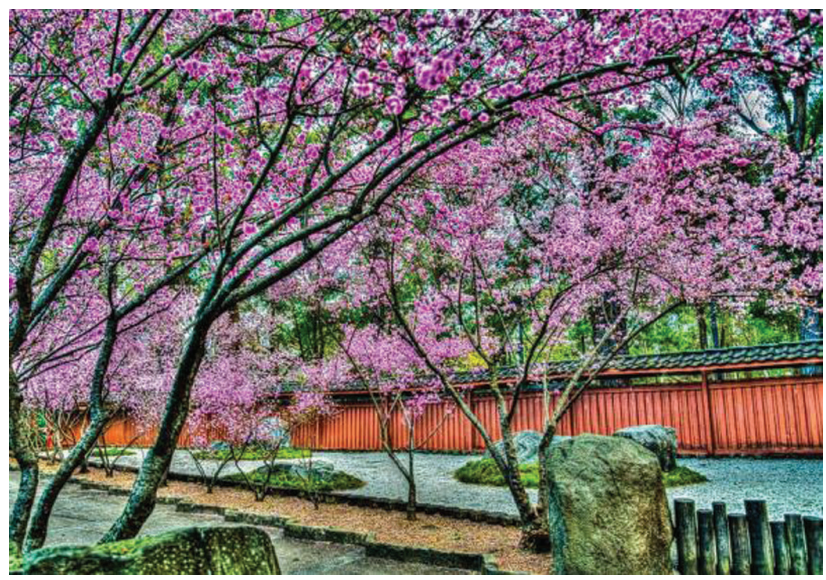

It is sometimes claimed that laughter is the best medicine ${ }^{[1,2]}$. Joking apart, it's probably better documented, and arguably more evidence-based (e.g. The King's Fund's 2016 Report 'Gardens and health: Implications for policy and practice' ${ }^{[3]}$ ), that 'communing with nature', plants and greenness in particular, is more likely of benefit to those whose health is compromised in one way or another (if only because too much laughing may cause one's stitches to come undone necessitating more medical intervention...). Reinforcing that notion (after all, the UK government via the NHS [National Health Service] ${ }^{[4]}$ wouldn't spend money if it wasn't going to be beneficial to the greater public good...) there is apparently both a resurgence of interest in, and use of, gardens in hospitals in the United Kingdom. As Juliet Dobson ${ }^{[5]}$ writes 'hospital gardens are making a comeback, and a growing number of hospitals across the UK benefit from gardens built specifically as a therapeutic space for patients.' Reportedly, such hospital gardens improved patients' sense of wellbeing, giving them a space to reflect, a sense of community, a support network and good company, and somewhere to go and meet other people experiencing the same challenges. And that's really good news for those of us whose own gardening attempts may be considered laughable. But, the therapeutic value of gardens and gardening may not be restricted to us Earth-dwellers. Raymond Odeh and Charles Guy propose that gardening should be an activity that is cultivated, and engaged in, by those involved in long-duration space missions ${ }^{[6]}$. Reviewing the growing literature on people-plant interactions as embodied in gardening and related activities, they conclude that the therapeutic benefits of that important activity could help to "mitigate potential psychosocial and neurocognitive decrements associated with long-duration space missions, especially for missions that seek to explore increasingly distant places where ground-based support is limited'. Reading that, I'm reminded of that intriguing film Silent Running ${ }^{[7]}$, where 'an astronaut is given orders to destroy the last of Earth's botany, kept in a greenhouse aboard a spacecraft'. He was not a happy bunny ${ }^{[8,9]}$ at that prospect...*

*Yes, I do acknowledge that in that rather dystopian film all flora on Earth had become extinct, so it's not an exact parallel with the modern day (yet...!), but the point about the beneficial effects of plants on space travellers still holds.

Image from: Wikimedia Commons

\section{References}

[1] https://www.helpguide.org/articles/mental-health/laughter-is-thebest-medicine.htm

[2] https://www.forbes.com/sites/daviddisalvo/2017/06/05/ six-science-based-reasons-why-laughter-is-the-bestmedicine/\#517292247f04

[3] https://www.kingsfund.org.uk/sites/default/files/field/field_publication_file/Gardens_and_health.pdf

[4] https://www.nhs.uk/NHSEngland/thenhs/about/Pages/overview. aspx

[5] $\quad B M J$ 2017;359: j5627 doi: 10.1136/bmj.j5627

[6] Open Agriculture 2: 1-13, 2017; doi: 10.1515/opag-2017-0001

[7] http://www.imdb.com/title/tt0067756/

[8] http://www.worldwidewords.org/qa/qa-hap4.htm

[9] https://www.collinsdictionary.com/dictionary/english/ not-a-happy-bunny 


\section{How much do you know about ... blowguns ${ }^{[1]}$ ?}

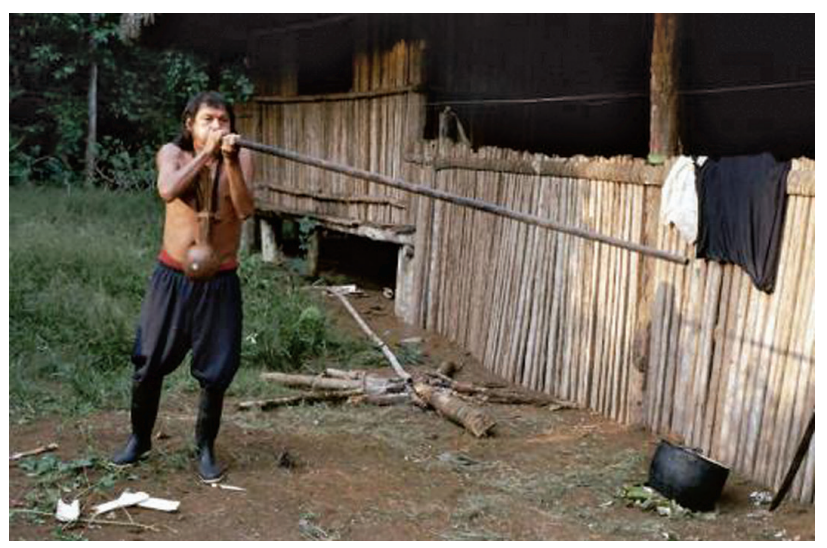

Not much I suspect. And it's probably not that important that any of us do in the so-called developed world where we don't need to hunt for meat using blowgun and poison-tipped darts ${ }^{[2]}$. And it's probably not as important nowadays for those living in areas where in days gone by that was a traditional method of hunting, e.g. in Amazonia or the forests of south-east Asia, because lifestyles for many have moved on. But, such traditional knowledge is important - whether it's still practised or not - because it is representative of the understanding that exists between people and the natural environment, particularly pertaining to the plant component. The potential for loss of that knowledge, which belongs to all humanity, was brought home to me by work of Elaine Schneider et al..$^{[3]}$. They examined traditional knowledge about palms (Arecaceae ${ }^{[4]}$ ) by the Chachi indigenous group ${ }^{[5,6]}$ in northwestern Ecuador. More importantly, they compared present day knowledge with that recorded 30 years before. Whilst four understorey palm species reported as useful previously were not recorded in 2015, pleasingly, most of the palm uses noted in 1985 were also registered in the recent study. However, and significantly, 'knowledge about blowguns, blowgun darts, and marimba keys*, seems to have vanished'. Whilst that knowledge still exists in the 1989 scientific paper, it is effectively lost from the collective knowledge of the people who could identify the plants that go with those uses. If this example of loss of traditional knowledge is globally representative, we risk losing important information that may harbour cures for the ills that plague human societies, or novel materials that could help create a more environmentally-sensitive, sustainable future. We don't know what's out there, and may never know if traditional knowledge is lost. We therefore need to keep in touch with our 'roots' - in both senses of the word ${ }^{[7]}$ ! - if we are to make the best use of all that nature has provided**. However it's not just about recording and documenting the knowledge, we also need to preserve and conserve the plants - and animals, fungi, bacteria, algae, etc. - that provide those wonderful natural resources. So, ethnobotany isn't just about blowguns, but it is about words, and it's also about actions. One Planet: One Chance to get it right.

*The marimba is a traditional percussion musical instrument (a sort of xylophone $e^{[8]}$ ) of the region, with its origins ultimately in Africa $^{[9,10]}$, and has a distinctive sound ${ }^{[11,12]}$.

**A timely example of the often unpredictable value of traditional plant knowledge is provided by Shameem Sultana Syeda et al. ${ }^{[13]}$ who demonstrate the potential of ouabain ${ }^{[14,15]}$ as a male contraceptive. Famously, ouabain is an arrow poison that is sourced from plants of the Strophanthus genus (Apocyanaceae) and was traditionally used by humans in hunting ${ }^{[16]}$. Rather than perpetuate its life-ending property, Western medicine has exploited this drug as a useful treatment for various heart conditions ${ }^{[17,18]}$ to enhance and prolong life in humans. Now, the compound's ability to interfere with $\mathrm{Na}^{+} / \mathrm{K}^{+}$ATPase activity ${ }^{[19,20]}$ has been effectively used to render male mice sterile, prompting this to be a step towards the creation of a male equivalent ${ }^{[21,22]}$ of the female oral contraceptive, 'the pill' ${ }^{[23]}$ for humans. From arrow-poison to procreation-inhibitor, the latter use probably couldn't have been predicted when this traditional knowledge of ouabain's effects was first noted, but such a use is now possible because that knowledge was passed on and shared. This is a dramatic example of what can be achieved with a little imagination, and underlines the need to ensure that the totality of human traditional and indigenous knowledge is fully recorded, and intelligently exploited.

[Ed. - for more studies on ethnobotanical potential of South America, and palms specifically, we've sourced these items for you: Joanna Sosnowska and Henrik Balslev ${ }^{[24]}$, Manuel Macía et al. ${ }^{[25]}$, and Rodrigo Cámara-Leret et al. ${ }^{[26]}$.]

Image from: Wikimedia Commons

\section{References}

[1] https://www.britannica.com/technology/blowgun

[2] http://frogs.cc/the-blowguns-and-darts-that-use-frog-poison/

[3] Econ. Bot. (2018). https://doi.org/10.1007/s12231-017-9397-8

[4] http://www.dipbot.unict.it/palms/Arec_fam.html

[5] ht t p://www.visitecuadorandsouthamerica.com/ learn-more-about-the-chachi-community-ecuador/

[6] h t t p s:// d e s tin a tionecuador.com/2013/11/ indigenous-tribes-live-ecuador/

[7] https://dictionary.cambridge.org/dictionary/english/root

[8] https://web.archive.org/web/20130619152601/http://www.xylophones.com/xylophone-history/

[9] https://www.vsl.co.at/en/Marimba/History/

[10] https://www.yamaha.com/en/musical_instrument_guide/marimba/ structure/

[11] https://www.youtube.com/watch?v=EWoRfthjbRw

[12] http://www.classicfm.com/music-news/videos/bach-marimba/

[13] Journal of Medicinal Chemistry, 2018; doi: 10.1021/acs. jmedchem.7b00925

[14] https://www.drugbank.ca/drugs/DB01092

[15] ht tp://tellmewhyfacts.com/science/2012/09/22/ poisonous-plants-that-will-kill-you-strophanthus-and-ouabain/

[16] https://www.botanical.com/botanical/mgmh/s/stroph96.html

[17] http://www.semmelweis.de/pdf/69_kracke_strophanthin.pdf

[18] https://www.botanical.com/botanical/mgmh/s/stroph96.html

[19] https://www.drugbank.ca/drugs/DB01092

[20] http://hyperphysics.phy-astr.gsu.edu/hbase/Biology/nakpump.html

[21] https://www.sciencedaily.com/releases/2018/01/180117164007.htm

[22] http://www.independent.co.uk/life-style/health-and-families/malecontraceptive-pill-arrow-poison-scientists-a8165541.html

[23] https://www.medicinenet.com/oral_contraceptives_birth_control_ pills/article.htm

[24] American palm ethnomedicine: A meta-analysis, Journal of Ethnobiology and Ethnomedicine 2009, 5: 43 doi: 10.1186/1746-4269-5-43

[25] Palm Uses in Northwestern South America: A Quantitative Review, Bot. Rev. 77: 462-570, 2011; doi: 10.1007/s12229-011-9086-8

[26] Ethnobotanical Knowledge Is Vastly Under-Documented in Northwestern South America, PLoS ONE 9(1): e85794. doi:10.1371/journal.pone.0085794

\section{Nigel Chaffey}

E-mail: n.chaffey@bathspa.ac.uk

Chaffey N. 2018. Plant Cuttings, Annals of Botany 121(4): iv-viii. 